\title{
Prognostic role of CD133 expression in colorectal cancer: a meta-analysis
}

Ke Wang ${ }^{1}$, Jianjun $\mathrm{Xu}^{2}$, Junshu Zhang ${ }^{1,3^{*}}$ and Jian Huang ${ }^{\text {* }^{*}}$

\begin{abstract}
Background: CD133 has been identified as a putative cancer stem cell marker in colorectal cancer (CRC). However, the clinical and prognostic significance of CD133 in CRC remains controversial.

Methods: Publications were identified which assessed the clinical or prognostic significance of CD133 in CRC up to October 2012. A meta-analysis was performed to clarify the association between CD133 expression and clinical outcomes.

Results: A total of 12 studies met the inclusion criteria, and comprised 3652 cases. Analysis of these data showed that CD133 was not significantly associated with the depth of CRC invasion (odds ratio [OR] $=1.44,95 \%$ confidence interval [Cl]: $0.77-2.68, Z=1.15, P=0.252)$ or tumor differentiation $(\mathrm{OR}=0.63,95 \% \mathrm{Cl}: 0.28-1.46, \mathrm{Z}=-1.06$, $P=0.286)$. Also, there was no statistically significant association of $C D 133$ with lymph node metastasis $(\mathrm{OR}=1.16$, $95 \% \mathrm{Cl}: 0.87-1.54, \mathrm{Z}=1.05, P=0.315)$ or lymphatic invasion ( $\mathrm{OR}=1.08,95 \% \mathrm{Cl}: 0.81-1.43, \mathrm{Z}=0.53, P=0.594)$. However, in identified studies, overexpression of CD133 was highly correlated with reduced overall survival (relative risk $[\mathrm{RR}]=2.14,95 \% \mathrm{Cl}: 1.45-3.17, \mathrm{Z}=3.81, P=0.0001)$.

Conclusions: CD133 may play an important role in the progression of CRC, and overexpression of CD133 is closely related with poorer patient survival. If these findings are confirmed by well-designed prospective studies, CD133 may be a useful maker for clinical applications.
\end{abstract}

Keywords: CD133, Cancer stem cell, Colorectal cancer, Prognosis

\section{Background}

Colorectal cancer (CRC) is one of the most common visceral malignancies and a leading cause of death worldwide. Increasing evidence suggests that cancers, including $\mathrm{CRC}$, may be hierarchically organized, with only a small population of cancer cells, termed cancer stem cells (CSCs), possessing the potential to initiate and sustain tumor growth and metastasis [1-3]. Furthermore, these cells are inert to toxic environmental agents owing to their high expression of ABC transporters, resistance to apoptosis, and efficient DNA repair mechanisms [4-6]. Thus, it is of major importance to investigate CSCs associated with cancer progression as they may be

\footnotetext{
* Correspondence: blzhjunshu@126.com; drhuangjian@zju.edu.cn ${ }^{1}$ Cancer Institute (Key Laboratory of Cancer Prevention \& Intervention, National Ministry of Education; Provincial Key Laboratory of Molecular Biology in Medical Sciences), Second Affiliated Hospital, Zhejiang University School of Medicine, Hangzhou 310009, China

${ }^{3}$ Department of Surgery, Linan People's Hospital, Hangzhou 311300, China Full list of author information is available at the end of the article
}

important factors in determining the clinical outcomes of cancer.

The cell surface marker CD133 (also known as prominin-1) is a five-domain transmembrane molecule, and has been identified as a putative CSC marker in various cancers, including brain tumors, prostate carcinoma and CRC [7-9]. Ricci-Vitiani et al. reported that CD133+ cells in CRC exhibited CSC properties in vitro and in vivo, such as self-renewal and high tumorigenic potential [10]. As few as 262 CD133+ CRC cells were able to form a tumor in NOD/SCID mice, whereas 10,000 CD133- cells failed. These suggested that CSCs had the ability to self-renew and to form the bulk of a tumor cell population.

The clinical relevance of CD133 is as a putative CSC marker in patients with CRC, where CSCs are thought to contribute to tumor progression and therapy resistance. Galizia et al. demonstrated that CD133 expression was correlated with clinical outcomes [11]. Overexpression of
C Biomed Central

(c) 2012 Wang et al.; licensee BioMed Central Ltd. This is an Open Access article distributed under the terms of the Creative Commons Attribution License (http://creativecommons.org/licenses/by/2.0), which permits unrestricted use, distribution, and reproduction in any medium, provided the original work is properly cited. 
CD133 was significantly associated with malignant transformation or poor clinicopathologic parameters in CRC. However, Kojima et al. showed that CD133 expression varied according to the histological type of cancer [12]. There is insufficient clinical data to confirm a clinical application for CD133. In order to address controversial issues, we performed a meta-analysis to determine the association between CD133 expression and clinicopathologic parameters.

\section{Materials and methods \\ Publication search}

Publications were identified in the PubMed database (http://www.ncbi.nlm.nih. gov/pubmed/) using the following search terms: "CD133", "colon cancer" or "colorectal cancer", and "overall survival" or "OS". Additional relevant searches were identified by manually crossreferencing abstracts of articles. Articles in this study were published up to October 2012. Titles and abstracts were evaluated to identify relevant publications, and the full text version scanned. The criteria for inclusion were: (1) articles dealing with CD133 expression and either prognostic factors or overall survival (OS) of CRC; (2) articles containing sufficient data to allow the estimation of an odds ratio (OR) or a relative risk (RR) of OS; (3) articles in the English language; and (4) articles published as original research. Reviews, comments, duplicated studies, and articles unrelated to our analysis were excluded. Studies with fewer than 50 patients, follow-up less than 2 years, and relevant articles using RT-PCR were also excluded.

The following information was extracted from the included papers: author, publication year, patient's country, tumor stage, number of patients, research technique used, antibody used, cutoff value of CD133, and tumor site. Two major groups were created according to the objective. One clarified the association between CD133 expression and clinicopathological parameters, including depth of invasion, degree of differentiation, lymph node status and lymphatic invasion. Another group investigated the association between CD133 expression and OS.

\section{Statistical analysis}

The meta-analysis was performed as previously described [13]. For ease of analysis, the following data of CD133 expression and clinicopathological factors were combined into single categories: CD133-negative and low; $\mathrm{T}_{1}$ and $\mathrm{T}_{2}$ stages; $\mathrm{T}_{3}$ and $\mathrm{T}_{4}$ stages; and well and moderate differentiation. ORs with $95 \% \mathrm{CI}$ were used to evaluate the association between CD133 expression and clinicopathological factors, including depth of invasion, differentiation, lymph node status and lymphatic invasion. Survival data were extracted from original papers as described by Parmar et al. [14]. Differences between CD133 expression and OS were quantified using RR with 95\% CI. Heterogeneity across studies was evaluated with the $\mathrm{Q}$ test and $P$ values. ORs and RRs were calculated by a random-effects model when the $P$ value was less than 0.05 . Otherwise, a fixedeffects model was used. Sensitivity analyses were performed to estimate the influence of individual studies on the summary effect. Funnel plots and Egger's regression test was used to assess publication bias. Statistical analyses were estimated using $\mathrm{R} /$ meta software. $P$ values were twosided, with significance at $P<0.05$.

\section{Results}

Description of studies

A total of 12 publications met the criteria for this analysis (Additional files 1 and 2) [12,15-25]. The total number of patients was 3652, ranging from 73 to 1235 patients per

Table 1 Main characteristics of the eligible studies

\begin{tabular}{|c|c|c|c|c|c|c|c|c|}
\hline Study & $\begin{array}{l}\text { Patient's } \\
\text { country }\end{array}$ & Year & $\begin{array}{l}\text { TNM } \\
\text { grading/UICC } \\
\text { staging }\end{array}$ & Technique & $\begin{array}{l}\text { Number } \\
\text { of patients }\end{array}$ & $\begin{array}{l}\text { Antibody used, } \\
\text { dilution }\end{array}$ & $\begin{array}{l}\text { Cutoff of } \\
\text { CD133 } \\
\text { positive }\end{array}$ & Site \\
\hline Coco & Italy & 2012 & $|-|||$ & $\mathrm{HHC}$ & 137 & Santa Cruz 100 & $>5 \%$ & Colon or Rectum \\
\hline Hongo & Japan & 2012 & I-IV & $\mathrm{HHC}$ & 303 & Miltenyi Biotec 100 & $>5 \%$ & Colon or Rectum \\
\hline Zhang & China & 2012 & $\|-I\|$ & $\mathrm{IHC}$ & 125 & Novus 150 & $\geq$ Score 4 & colon \\
\hline$X_{i}$ & China & 2011 & I-IV & $\mathrm{HC}$ & 201 & Abcam 200 & $\geq$ Score 5 & Colon or Rectum \\
\hline Lugli & Switzerland & 2010 & I-IV & Tissue microarray & 1235 & Cell Signaling 100 & $>5 \%$ & Colon or Rectum \\
\hline Takahashi & Japan & 2010 & I-IV & $\mathrm{HC}$ & 151 & Abcam 200 & $>50 \%$ & Colon or Rectum \\
\hline Ong & Australia & 2010 & I-IV & Tissue microarray & 501 & Miltenyi Biotech 10 & $>5 \%$ & Colon or Rectum \\
\hline $\mathrm{Li}$ & China & 2009 & $\| \mathrm{I} B$ & $\mathrm{HC}$ & 104 & Abcam 150 & $\geq 5 \%$ & Colon or Rectum \\
\hline Horst & Germany & 2009 & $|-| \mid$ & $\mathrm{HC}$ & 110 & Cell Signaling 100 & $\geq 50 \%$ & Colon \\
\hline Choi & South Korea & 2009 & O-IV & Tissue microarray & 523 & Santa Cruz 50 & - & Colon or Rectum \\
\hline Wang & China & 2009 & O-IV & $\mathrm{IHC}$ & 73 & Abcam 200 & $>10 \%$ & Rectal \\
\hline Kojima & Japan & 2008 & I-IV & $\mathrm{IHC}$ & 189 & Miltenyi Biotech 100 & $>10 \%$ & Colon or Rectum \\
\hline
\end{tabular}




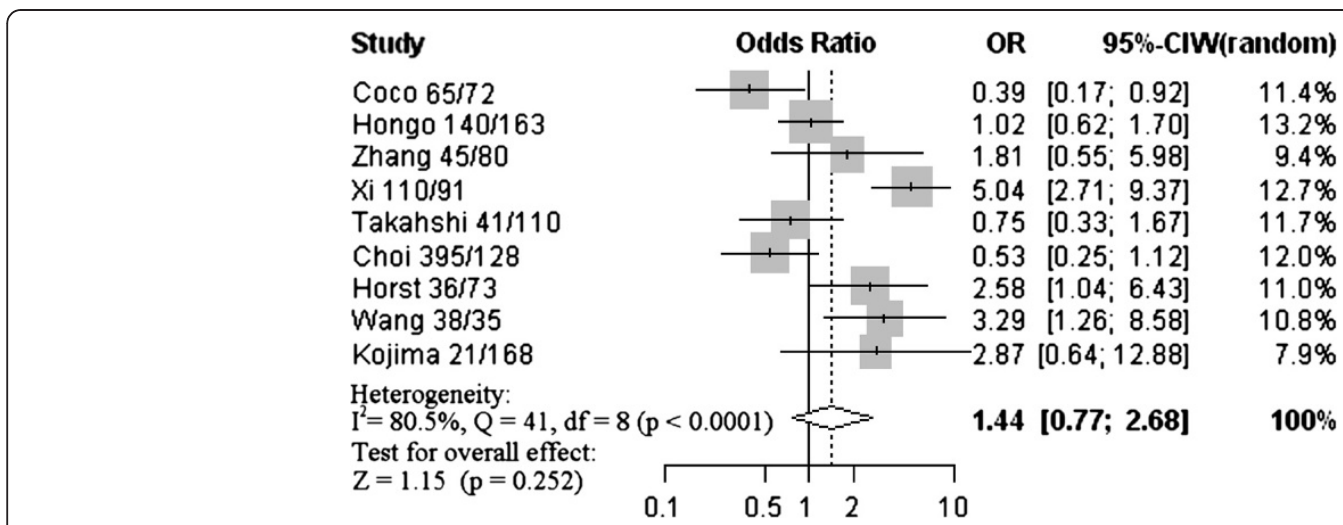

Figure 1 Forrest plot of odds ratios (ORs) for the association of CD133 expression with depth of invasion.

study. Main characteristics of the eligible studies were summarized in Table 1 . Nine articles dealt with clinicopathological factors. Nine studies determined with OS. Three studies only reported the association between CD133 expression and clinicopathological factors without OS analysis. There were mainly two kinds of methods used to evaluate CD133 expression in CRC specimens: immunohistochemistry (IHC) and tissue microarray.

\section{Correlation of CD133 expression with clinicopathological parameters}

Nine studies assessed the relationship between CD133 phenotype and depth of invasion (Figure 1). The pooled OR was 1.44 (95\% CI: $0.77-2.68, \mathrm{Z}=1.15, P=0.252$ random-effect), and there was no significant heterogeneity, suggesting CD133 expression was not associated with depth of invasion. Five studies investigated the relationship between CD133 expression and degree of differentiation (Figure 2). There was no statistically significant association of CD133 and tumor differentiation (pooled $\mathrm{OR}=0.63,95 \%$ CI: $0.28-1.46, \mathrm{Z}=-1.06, P=0.286$ random-effect). There was also no association between CD133 expression and clinical parameters such as lymph node metastasis (pooled OR $=1.16,95 \%$ CI: 0.87-1.54, $\mathrm{Z}=1.05, P=0.315$ fixed-effect) (Figure 3 ) or lymphatic invasion (pooled OR $=1.08,95 \% \mathrm{CI}: 0.81-1.43, \mathrm{Z}=0.53$, $P=0.594$ fixed-effect) (Figure 4). Moreover, Egger's test indicated that above clinicopathological parameters showed no significant publication bias (Additional file 3).

\section{Impact of CD133 expression on overall survival of colorectal cancer}

The meta-analysis was performed on nine studies (1581 patients) investigating the association of CD133 expression and OS. The pooled RR was calculated using the methods described above. As the test for heterogeneity was significant $(P<0.0001)$, a random-effect model was used to calculate the RR. The presence of CD133 expression was highly correlated with poor OS (pooled $\mathrm{RR}=2.14,95 \% \mathrm{CI}: 1.45-3.17, \mathrm{Z}=3.81, P=0.0001)$ (Figure 5). This indicated that $\mathrm{CD} 133$ was an independent prognostic factor in CRC. No significant publication bias was detected (Additional file 3), and the explanatory variables did not significantly influence $R R$ estimates for OS (Additional file 4).

\section{Discussion and conclusion}

To our knowledge, the present meta-analysis is the first English language study to systematically determine the association between CD133 expression and CRC survival. As the prognostic and predictive significance of the CD133 phenotype in CRC was controversial, a quantitative meta-analysis of the study outcomes was warranted. Our analysis indicated that CD133 expression

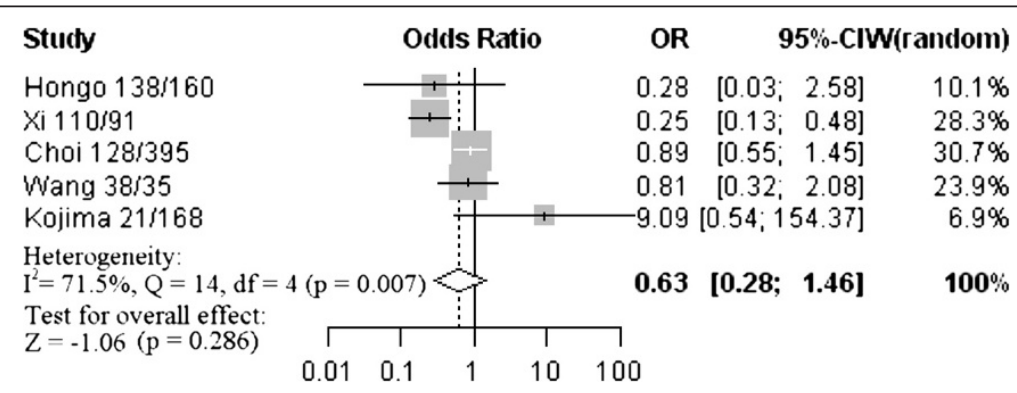

Figure 2 Forrest plot of ORs for the association of CD133 expression with tumor differentiation. 


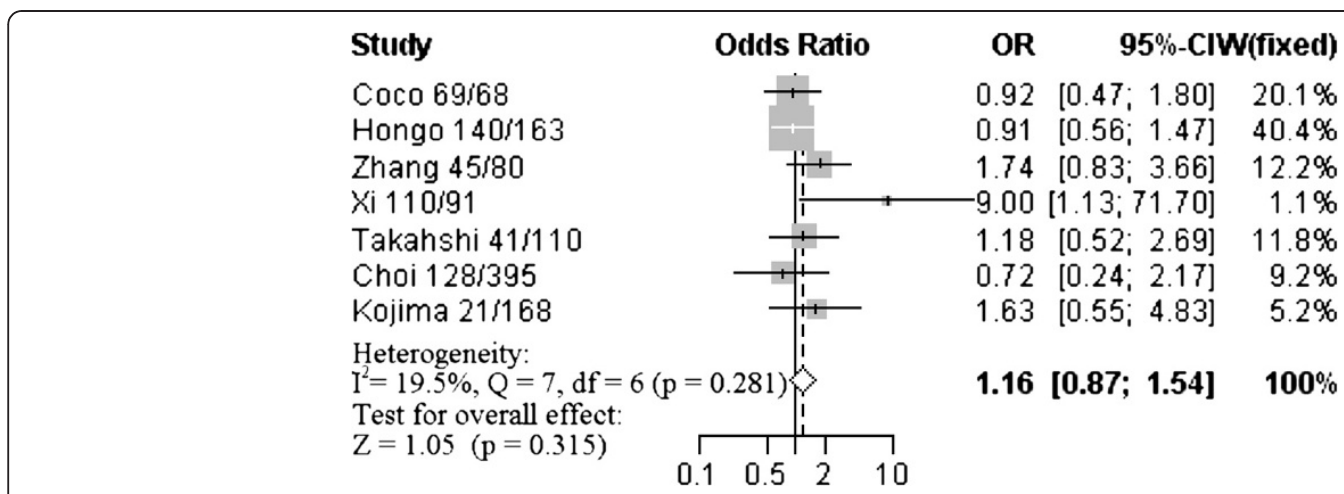

Figure 3 Forrest plot of ORs for the association of CD133 expression with lymph node metastasis.

was significantly associated with OS, indicating that it might be a marker for poor prognosis of CRC.

CD133 is the epitope of a glycosylated form of membrane protein, and the physiological function of CD133 remains unknown. It was originally classified as a potential CSC marker in CRC. Ieta et al. reported that CRC tissue had much higher CD133 protein expression than that of normal tissue [26]. In our study, the data showed that CD133 was not positively correlated to the depth of invasion or degree of tumor differentiation. Although lymph node metastasis and lymphatic invasion were more common in cases with high CD133 than in those with CD133-negative or low, the differences were not statistically significant. Concerning the prognostic value of CD133, a few papers reported significant associations with CRC, and that CD133 might be considered as a new marker to determine the stage and management of CRC [20,27]. It is notable that this association is observed in our meta-analysis of CD133 phenotype and OS, suggesting that this marker can be developed for clinical applications.

For future studies, co-expression of colorectal CSC markers associated with patient survival may be more meaningful for clinical application in CRC. Several studies have shown that CSC-related factors, including ALDH1 and LGR5, are associated with cancer progression [28,29]. In addition, CSCs have major phenotypic and functional heterogeneity which may help distinguish them from cancer cells, and may be of potential benefit in the development of anti-cancer therapies to improve clinical outcomes [30].

Certain limitations exist in this meta-analysis. First, OS was determined from unadjusted RRs in the published papers, and RRs from the survival curves might be less reliable than direct analysis of variance. Ideally, measurements should be obtained directly from published statistics and adjusted using other prognostic factors. Second, the patient populations were not uniform, e.g., Choi et al. focused on patients with invasiveness and differentiation of CRC [25], while all the patients in the Ong et al. study received neoadjuvant chemotherapy [19]. These differences might partly influence the significance of the clinicopathological outcome in survival analyses.

In summary, this meta-analysis indicated that CD133 expression was not associated with common clinical parameters of CRC, such as depth of invasion, tumor differentiation, lymph node metastasis and lymphatic permeation. However, high CD133 expression was associated with a worse outcome than CD133-negative or -low expression, and CD133 was an independent factor associated with reduced survival. Further studies of CD133 and its potential as a marker for CRC prognosis in clinic are warranted.

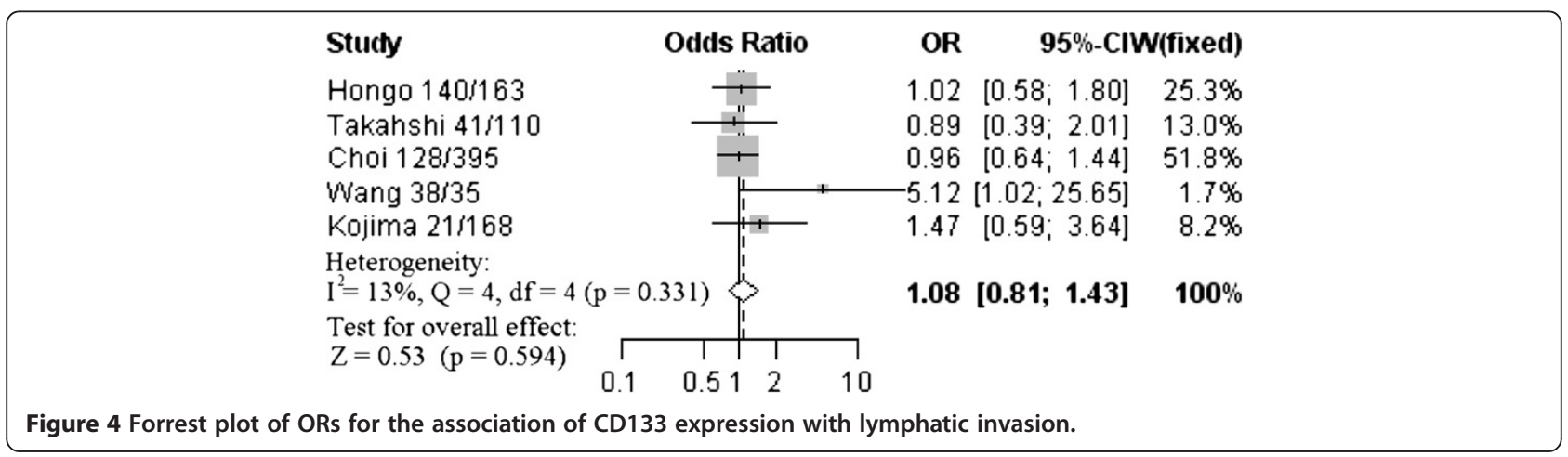




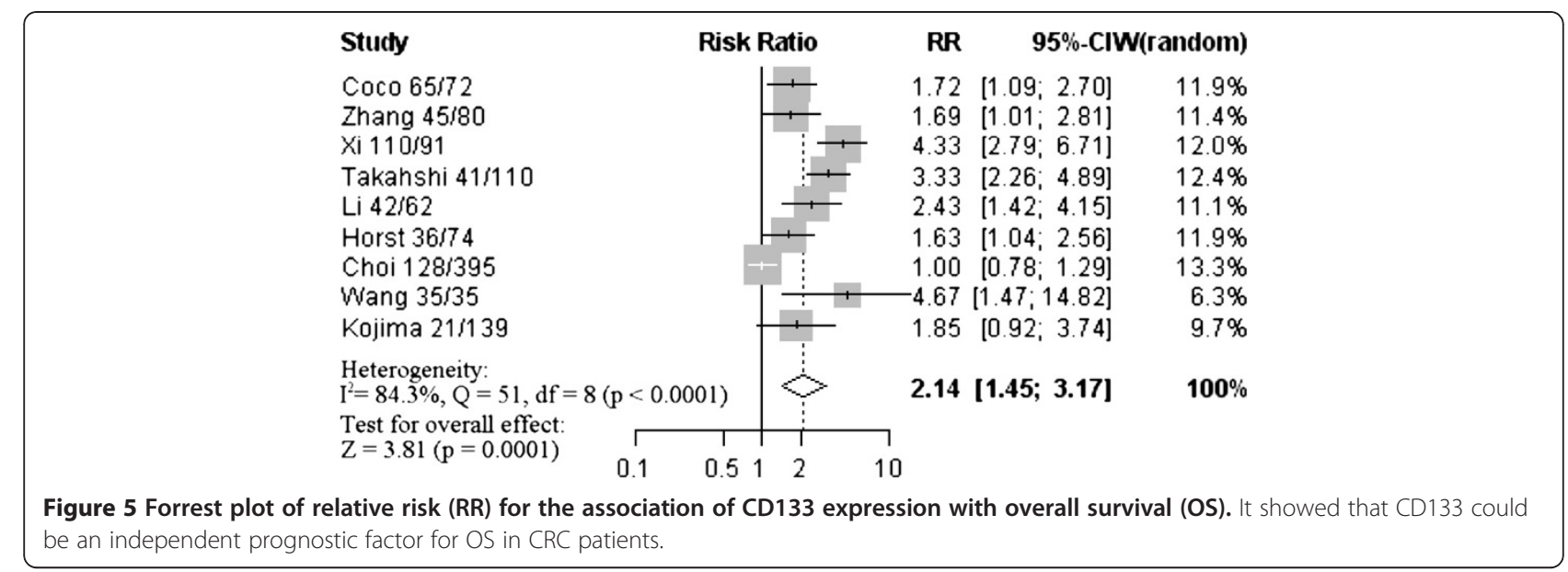

\section{Additional files}

\section{Additional file 1: PRISMA 2009 Flow Diagram.}

Additional file 2: PRISMA 2009 Checklist.

Additional file 3: Egger's test of funnel plot asymmetry.

Additional file 4: Results of meta-regression analysis exploring source of heterogeneity with overall survival.

\section{Abbreviations}

Cl: Confidence interval; CRC: Colorectal cancer; CSC: Cancer stem cell; IHC: Immunohistochemistry; OR: Odds ratio; OS: Overall survival; RR: Relative risk.

\section{Competing interests}

The authors declare that they have no competing interests.

\section{Authors' contributions}

KW participated in extracting the data and wrote the manuscript. JX performed the statistical analysis. JH and JZ carried out literature search and data collection. All authors approved the final manuscript.

\section{Acknowledgments}

We are grateful for financial supports by National Natural Science Foundation of China (91019005 and 81272672), 151 Talent Project of Zhejiang Province $(\mathrm{HJ})$, and Zhejiang Provincial Program for the Cultivation of High-level Innovative Health Talents (HJ). Ph.D. Programs Foundation of Ministry of Education of China (20100101110124), Zhejiang Provincial Natural Science Foundation of China (Grant No. Z2100366 and Y2100414).

\section{Author details}

${ }^{1}$ Cancer Institute (Key Laboratory of Cancer Prevention \& Intervention, National Ministry of Education; Provincial Key Laboratory of Molecular Biology in Medical Sciences), Second Affiliated Hospital, Zhejiang University School of Medicine, Hangzhou 310009, China. ${ }^{2}$ School of Finance, Zhejiang University of Finance and Economics, Hangzhou 310009, China. ${ }^{3}$ Department of Surgery, Linan People's Hospital, Hangzhou 311300, China.

Received: 11 August 2012 Accepted: 27 November 2012 Published: 5 December 2012

\section{References}

1. Reya T, Morrison SJ, Clarke MF, Weissman IL: Stem cells, cancer, and cancer stem cells. Nature 2001, 414:105-111.

2. Ailles LE, Weissman IL: Cancer stem cells in solid tumors. Curr Opin Biotechnol 2007, 18:460-466.

3. Wang K, Liu L, Zhang T, Zhu YL, Qiu F, Wu XG, Wang XL, Hu FQ, Huang J:
Oxaliplatin-incorporated micelles eliminate both cancer stem-like and bulk cell populations in colorectal cancer. Int J Nanomedicine 2011, 6:3207-3218.

4. Dean $M: A B C$ transporters, drug resistance, and cancer stem cells. J Mammary Gland Biol Neoplasia 2009, 14:3-9.

5. Fulda S, Pervaiz S: Apoptosis signaling in cancer stem cells. Int J Biochem Cell Biol 2010, 42:31-38.

6. Rich JN, Bao S: Chemotherapy and cancer stem cells. Cell Stem Cell 2007 1:353-355.

7. Yin AH, Miraglia S, Zanjani ED, Almeida-Porada G, Ogawa M, Leary AG, Olweus J, Kearney J, Buck DW: AC133, a novel marker for human hematopoietic stem and progenitor cells. Blood 1997, 90:5002-5012

8. Uchida N, Buck DW, He D, Reitsma MJ, Masek M, Phan TV, Tsukamoto AS, Gage FH, Weissman IL: Direct isolation of human central nervous system stem cells. Proc Natl Acad Sci U S A 2000, 97:14720-14725.

9. Collins AT, Berry PA, Hyde C, Stower MJ, Maitland NJ: Prospective identification of tumorigenic prostate cancer stem cells. Cancer Res 2005, 65:10946-10951.

10. Ricci-Vitiani L, Lombardi DG, Pilozzi E, Biffoni M, Todaro M, Peschle C, De Maria R: Identification and expansion of human colon-cancer-initiating cells. Nature 2007, 445:111-115.

11. Galizia G, Gemei M, Del Vecchio L, Zamboli A, Di Noto R, Mirabelli P, Salvatore F, Castellano P, Orditura M, De Vita F, et al: Combined CD133/ CD44 expression as a prognostic indicator of disease-free survival in patients with colorectal cancer. Arch Surg 2012, 147:18-24.

12. Kojima M, Ishii G, Atsumi N, Fujii S, Saito N, Ochiai A: Immunohistochemical detection of CD133 expression in colorectal cancer: a clinicopathological study. Cancer Sci 2008, 99:1578-1583.

13. Zhou L, Jiang $Y$, Yan T, Di G, Shen Z, Shao Z, Lu J: The prognostic role of cancer stem cells in breast cancer: a meta-analysis of published literatures. Breast Cancer Res Treat 2010, 122:795-801.

14. Parmar MK, Torri V, Stewart L: Extracting summary statistics to perform meta-analyses of the published literature for survival endpoints. Stat Med 1998, 17:2815-2834

15. Lugli A, lezzi G, Hostettler I, Muraro MG, Mele V, Tornillo L, Carafa V, Spagnoli G, Terracciano L, Zlobec I: Prognostic impact of the expression of putative cancer stem cell markers CD133, CD166, CD44s, EpCAM, and ALDH1 in colorectal cancer. Br J Cancer 2010, 103:382-390.

16. Takahashi S, Kamiyama T, Tomaru U, Ishizu A, Shida T, Osaka M, Sato Y, Saji $Y$, Ozaki M, Todo S: Frequency and pattern of expression of the stem cell marker CD133 have strong prognostic effect on the surgical outcome of colorectal cancer patients. Oncol Rep 2010, 24:1201-1212.

17. Li CY, Li BX, Liang Y, Peng RQ, Ding Y, Xu DZ, Zhang X, Pan ZZ, Wan DS, Zeng $Y X$, et al: Higher percentage of CD133+ cells is associated with poor prognosis in colon carcinoma patients with stage IIIB. J Trans/ Med 2009, 7:56.

18. $\mathrm{Xi} \mathrm{HQ}$, Zhao $\mathrm{P}$ : Clinicopathological significance and prognostic value of 
EphA3 and CD133 expression in colorectal carcinoma. J Clin Pathol 2011, 64:498-503.

19. Ong CW, Kim LG, Kong HH, Low LY, lacopetta B, Soong R, Salto-Tellez M: CD133 expression predicts for non-response to chemotherapy in colorectal cancer. Mod Pathol 2010, 23:450-457.

20. Wang Q, Chen ZG, Du CZ, Wang HW, Yan L, Gu J: Cancer stem cell marker CD133+ tumour cells and clinical outcome in rectal cancer. Histopathology 2009, 55:284-293.

21. Horst D, Kriegl L, Engel J, Kirchner T, Jung A: Prognostic significance of the cancer stem cell markers CD133, CD44, and CD166 in colorectal cancer. Cancer Invest 2009, 27:844-850.

22. Coco C, Zannoni GF, Caredda E, Sioletic S, Boninsegna A, Migaldi M, Rizzo G, Bonetti LR, Genovese G, Stigliano E, et al: Increased expression of CD133 and reduced dystroglycan expression are strong predictors of poor outcome in colon cancer patients. J Exp Clin Cancer Res 2012, 31:71.

23. Hongo K, Kazama S, Sunami E, Tsuno NH, Takahashi K, Nagawa H, Kitayama $\mathrm{J}$ : Immunohistochemical detection of CD133 is associated with tumor regression grade after chemoradiotherapy in rectal cancer. Med Oncol 2012, 29:2849-2857.

24. Zhang NH, Li J, Li Y, Zhang XT, Liao WT, Zhang JY, Li R, Luo RC: Coexpression of CXCR4 and CD133 proteins is associated with poor prognosis in stage II-III colon cancer patients. Exp Ther Med 2012, 3:973-982.

25. Choi D, Lee HW, Hur KY, Kim JJ, Park GS, Jang SH, Song YS, Jang KS, Paik SS: Cancer stem cell markers CD133 and CD24 correlate with invasiveness and differentiation in colorectal adenocarcinoma. World I Gastroenterol 2009, 15:2258-2264.

26. leta K, Tanaka F, Haraguchi N, Kita Y, Sakashita H, Mimori K, Matsumoto T, Inoue $\mathrm{H}$, Kuwano $\mathrm{H}$, Mori M: Biological and genetic characteristics of tumor-initiating cells in colon cancer. Ann Surg Oncol 2008, 15:638-648.

27. Artells R, Moreno I, Diaz T, Martinez F, Gel B, Navarro A, Ibeas R, Moreno J, Monzo M: Tumour CD133 mRNA expression and clinical outcome in surgically resected colorectal cancer patients. Eur J Cancer 2010, 46:642-649

28. Vogler T, Kriegl L, Horst D, Engel J, Sagebiel S, Schaffauer AJ, Kirchner T, Jung A: The expression pattern of aldehyde dehydrogenase 1 (ALDH1) is an independent prognostic marker for low survival in colorectal tumors. Exp Mol Pathol 2012, 92:111-117.

29. Gerger A, Zhang W, Yang D, Bohanes P, Ning Y, Winder T, LaBonte MJ, Wilson PM, Benhaim L, Paez D, et al: Common cancer stem cell gene variants predict colon cancer recurrence. Clin Cancer Res 2011, 17:6934-6943.

30. Tang DG: Understanding cancer stem cell heterogeneity and plasticity. Cell Res 2012, 22:457-472.

doi:10.1186/1471-2407-12-573

Cite this article as: Wang et al: Prognostic role of CD133 expression in colorectal cancer: a meta-analysis. BMC Cancer 2012 12:573.

\section{Submit your next manuscript to BioMed Central and take full advantage of:}

- Convenient online submission

- Thorough peer review

- No space constraints or color figure charges

- Immediate publication on acceptance

- Inclusion in PubMed, CAS, Scopus and Google Scholar

- Research which is freely available for redistribution

Submit your manuscript at www.biomedcentral.com/submit
C Biomed Central 